\title{
Prototype of Improved Green Neo-Local West Sumatera Stove for Boiling Gambir (Uncaria Gambir Roxb.)
}

\author{
Firdaus $^{1}$, Muhammad Hatta Dahlan ${ }^{2}$, Muhammad Faizal $^{3}$, Kaprawi $^{3} \&$ Susila $_{\text {Arita }^{3}}$ \\ ${ }^{1}$ Student of Doctoral Program of Environmental Science, Sriwijaya University, Palembang, Indonesia \\ ${ }^{2}$ Promotor \\ ${ }^{3}$ Co-promotors \\ Correspondence: Firdaus, Student of Doctoral Program of Environmental Science, Sriwijaya University, \\ Palembang, Indonesia. E-mail: firdausftimtdr@gmail.com
}

Received: November 20, 2014 Accepted: December 3, 2014 Online Published: January 28, 2015

doi:10.5539/jsd.v8n1p83

URL: http://dx.doi.org/10.5539/jsd.v8n1p83

\begin{abstract}
Study of Local West Sumatera Stove performances to boil gambir in Pesisir Selatan district showed the results that heat transfer efficiency is $11.6 \%$, very simple in operation but short service life, indoor pollution due to smoke and burnt risk are high because of no chimney and hot flue gas temperature is still higher than $200{ }^{\circ} \mathrm{C}$, very cheap in construction, and environmentally causes impact on local deforestation. This paper attempted to design, construct, and run a set of combustion test to NWS Stove for boiling gambir using mixture of biomass fuel of fire-wood, palm fiber and shell. It was made of river stones and consists of two main parts, namely combustion chamber with grate for biomass fuel bed and its pot and flue gas heat utilization. Water Boiling Test was conducted with the height of grate of 25 to $45 \mathrm{~cm}$ from the floor, natural or forced convection air underneath the grate, damper between combustion chamber and flue gas channel to the chimney was 10 to $20 \mathrm{~cm}$ height opened, and kinds and mixtures of biomass with any quantitative proportion. The result shows that the stove is green and saves the fire-wood fuel $70 \%$ or more. It also shows performances as follow: higher heat transfer efficiency, namely up to $18.78 \%$; very simple in operation and long service life; gives more benefits in health and safety; needs higher capital investment but low operational cost. Additionally, temperature profiles show that adjustable grate with distance to cooking pot not more than $25 \mathrm{~cm}$ probably plays an important role in effective heat transfer.
\end{abstract}

Keywords: heat efficiency, stove, fiber, shell, grate, and damper

\section{Introduction}

Gambir (Uncaria Gambir Roxb.) is one of traditional export commodity of West Sumatera Province. Preliminary study showed that 8 tons of dried extract gambir is produced per week using Local West Sumatera stove (LWS Stove) in 400 "rumah kempa" home industries operates every day in Pesisir Selatan district. LWS Stove is made of clay and surrounded by clay. It is too high in construction (about $80 \mathrm{~cm}$ ), no grate for fuel bed in combustion chamber, and no chimney so that hot flue gas temperature exit is too high. The hot flue gas temperature is normally in range of 200 to $250{ }^{\circ} \mathrm{C}$, depend on the flare. These reasons lead to low efficiency of LWS Stove. The large distance between the pot and fuel bed causes heat transfer to cooking pot to be considerably reduced. Because of the large size of flue gas exits between the cooking pot and stove, much of the hot flue gas exits the stove without coming into contact with the cooking pot, thus reducing the convective heat transfer. Then, no grate makes air cannot reach the bottom of the stove than a considerable amount of fuel accumulates at the bottom as charcoal.

Water Boiling Test for preliminary study showed that heat efficiency of LWS Stove defined as heat absorb by water devided by heat combustion of fire-wood was $11.6 \%$. The improve stove like Cottage Basin applied in silk-reeling industry in India promises heat efficiency slightly higher than 15\%.

The LWS Stove is operated twice a year with operating time for one period was around four to five weeks, depand on leaves and branches quantity harvested after five months each. For each five months period, the stove needs to be repaired before being operated. In other words, its service life is too short, namely only for one period of production. 
In health and safety view point, the LWS Stove releases dirty hot flue gas which gives impact to workers. Not only the workers possibly suffer breathless but also burn by spark of fire. Moreover, plastics waste used to coat the pot hole to prevent leakage between the pot hole and boiling pan is harmful to respiratory.

In economics aspect, the stove is very cheap. It only needs around 20 USD per period of production, namely for buying one sack of cement and payment for handyman to repair the stove in the beginning of every production period. While cost for fire-wood was around 40 USD to produce 1 tone of mold extract gambir.

In environmental aspect, four hundreds of LWS Stoves operated in Pesisir Selatan district need 20 tons of fire-wood every day leading to local deforestation. Meanwhile, there are nineteen Crude Palm Oil (CPO) mills in West Sumatera with total capacity of more than 10 million tons of fresh fruit bunch in the year of 2012. Then, more than 2.3 millions tons of empty fruit bunch, 1.1 millions tons of fiber, and 0.6 million shell potentially available in the year of 2012 to be used for biomass fuel.

It is necessary to introduce improved stove for boiling gambir in West Sumatera called Neo-local West Sumatera Stove (NWS Stove) to reduce local deforestation impact. Design of the NWS Stove was conducted to get improved and green stove which fulfilled the needs for higher heat efficiency, longer service life and simple operation, health and safety, economics, and could overcome local deforestation impact. Comprehensive study showed that among many improved stoves in the world, three types presented in Figure 1 are interest to be the basic model for prototype of NWS Stove. Plancha, Patsari, and Justa Stoves are claimed to reduce fire-wood need up to $70 \%$. There are grates for biomass bed, chimney, and units for heat utilization in these improved stoves.
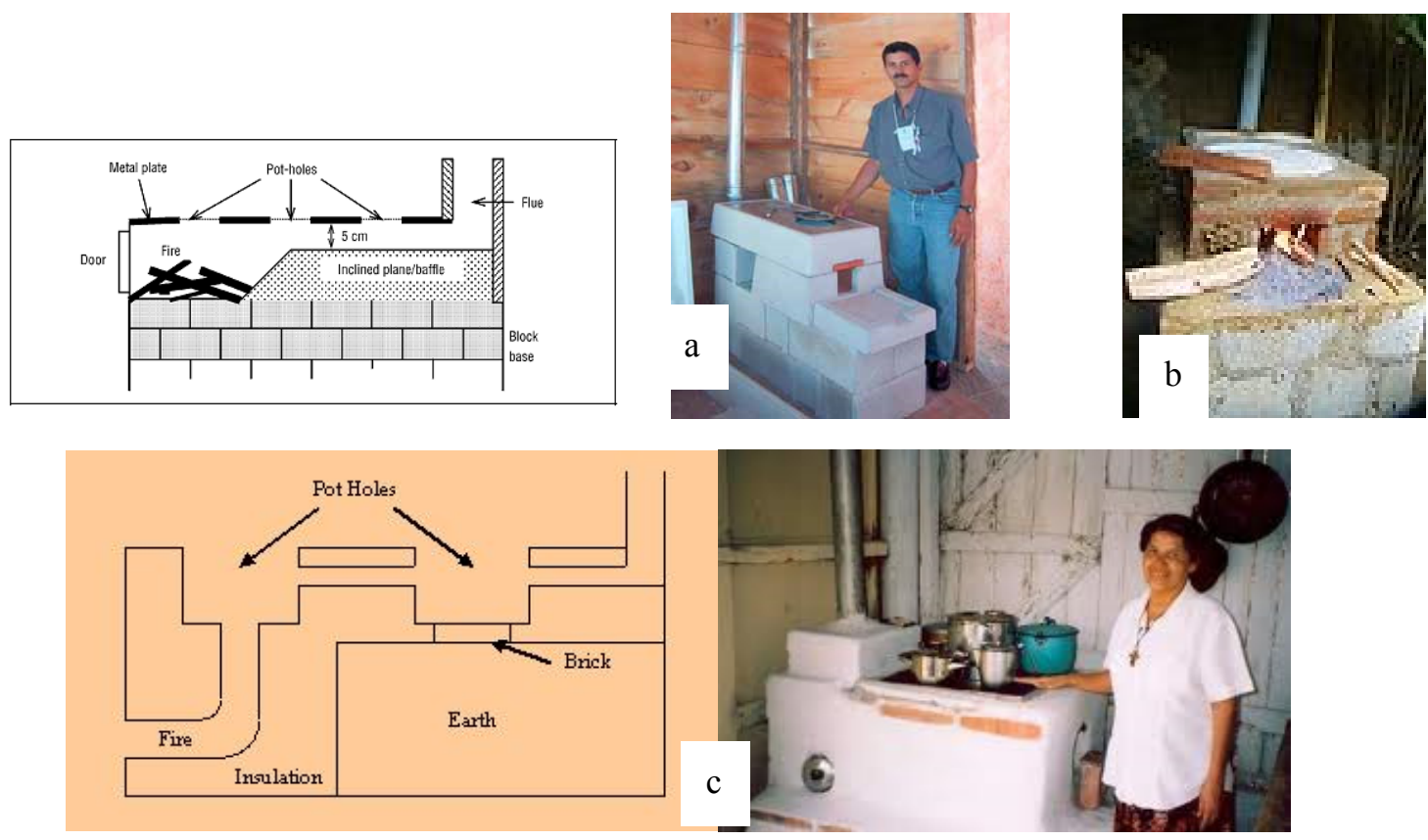

Figure 1. a) Basic concept and typical of Plancha stove; b) Patsari stove; and c) Basic concept and typical of Justa stove

This paper attempted to design and construct a prototype of improved green NWS Stove for boiling gambir and to run a set of combustion test using less or no fire-wood fuel by introducing palm fiber and shell as substitution fuel.

\section{Method}

This study consists of three main steps, namely design, construction, and combustion test of prototype of NWS Stove. Cottage Basin Stove applied in silk-reeling industry presented in Figure 2 is adopted in designing NWS Stove. The influenced of parameters to performances of the stove such as the height of grate, opening for entrance air, damper between combustion chamber and hot flue gas channel to chimney, and damper on the chimney are highlighted. The design of the NWS Stove and its compartments using material construction of river stone has been presented in The $4^{\text {th }}$ International Seminar on Environmental Engineering in Bali 2013. Prototype of NWS Stove constructed with two main parts, namely combustion chamber and its pot and flue gas heat 
utilization. The first part construction was built by an experienced mason. Meanwhile, tray drier for flue gas heat utilization was built in workshop.

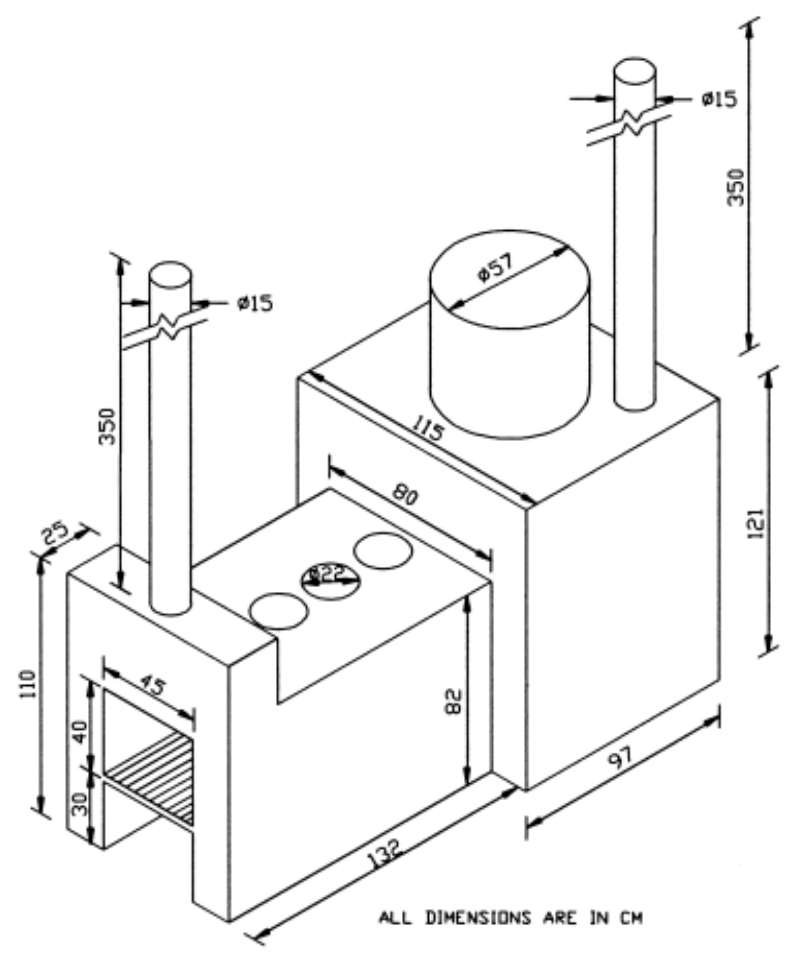

Figure 2. Cottage basin stove applied in silk-reeling industry

Water Boiling Test (WBT) method was used in combustion test. Combustion test of NWS Stove using fire-wood, palm fiber and shell, and their mixture as fuels was conducted under conditions as follow: full opened combustion chamber opening and damper at the chimney; addition of $25 \mathrm{ml}$ kerosene as ignition fuel; and 2000 $\mathrm{ml}$ water test in the pan. The WBT was conducted by varying some parameters, namely: the height of grate in the range of 25 to $45 \mathrm{~cm}$ from the floor of combustion chamber; natural or forced convection air underneath the grate; 2.5 to $20 \mathrm{~cm}$ height opened of damper between combustion chamber and flue gas channel to the chimney; and kinds of biomass fuel and their quantitative proportion used in the mixtures.

Combustion proceed is classified in three categories, namely successful, bad, or failed. Successful combustion is defined as combustion signed by relatively stable flare till all of biomass fuel compounds had burnt out except char and ash. Bad combustion is defined as combustion signed by little to bigger flame and then dimmed while less than one third of biomass had burnt. Failed combustion is defined as combustion signed by small flame and dimmed before biomass had burnt significantly.

Temperature profile in combustion chamber was prepared by measuring temperature spots in chamber as long as combustion going on using infrared thermometer. The temperature measurement was started after 5 minutes combustion and finished as the flame was off. The measurement of temperature on kerosene and LPG stoves was conducted to give comparatives value. The temperature measurement of $T_{1}, T_{2}$, and $T_{3}$ in combustion chamber was set at the points near the bottom $\left(T_{1}\right)$, middle $\left(T_{2}\right)$, and near the pot $\left(T_{3}\right)$ respectively with the difference height distance of $10 \mathrm{~cm}$. As infrared thermometer measures temperature of solid body then values of $T_{1}, T_{2}$, and $T_{3}$ represent temperatures of iron rod heated in combustion chamber. Plot data temperatures $T_{1}, T_{2}$, and $T_{3}$ versus time give temperature profiles describe biomass combustion steps going on in the chamber. Temperatures oven and chimney was measured on the inner wall for the same reason.

\section{Results and Discussion}

Construction of NWS Stove and its compartments which could operate simply are given in Figure 3 . In economic view point, it needs capital investment minimal 50 USD to build the stove but it might stand for many years. Meanwhile, the results of combustion test using biomass fuel of fire-wood, fiber, shell, and their mixtures 
to know the performances of the stove for natural convection and force convection air are given in Table 1 and 2 , respectively.

Table 1. Results of combustion test (natural convection air)

\begin{tabular}{|c|c|c|c|c|c|c|c|}
\hline \multirow[t]{2}{*}{$\begin{array}{l}\text { Damper } \\
\text { opened, cm }\end{array}$} & \multirow{2}{*}{$\begin{array}{l}\text { The height of } \\
\text { grate from the } \\
\text { floor, cm }\end{array}$} & \multirow[t]{2}{*}{ Biomass fuel $/ \mathrm{kg}$} & \multirow[t]{2}{*}{$\begin{array}{l}\text { Combustion } \\
\text { proceed }\end{array}$} & \multirow{2}{*}{$\begin{array}{l}\text { Time to boil } \\
\text { the water, } \\
\text { minute }\end{array}$} & \multirow{2}{*}{$\begin{array}{l}\text { Average rate of } \\
\text { water vaporized, } \\
\mathrm{ml} / \text { minute }\end{array}$} & \multicolumn{2}{|c|}{$\begin{array}{l}\text { Maximum } \\
\text { temperature, }{ }^{0} \mathrm{C}\end{array}$} \\
\hline & & & & & & oven & Chimney \\
\hline & & fire-wood/ 2 & Failed & - & - & - & - \\
\hline \multirow[t]{3}{*}{2.5} & 25 & shell/ 2 & Failed & - & - & - & - \\
\hline & & fiber/ 2 & Successful & - & - & 48 & 38 \\
\hline & & fire-wood/ 2 & Successful & 6.8 & 20 & 81 & 58 \\
\hline \multirow[t]{2}{*}{10} & 45 & shell/ 2 & Failed & - & - & - & - \\
\hline & & fiber/ 2 & Successful & - & - & 41 & 38 \\
\hline 15 & 45 & fire-wood/ 2 & Successful & 4.8 & 18.2 & 75 & 53 \\
\hline 20 & 45 & fire-wood/ 2 & Successful & 5.25 & 17.9 & 94 & 63 \\
\hline 15 & 45 & $\begin{array}{l}\text { fiber : shell/ } \\
1.5: 1.5\end{array}$ & Successful & 24 & 10 & 44 & 38 \\
\hline 15 & 45 & $\begin{array}{l}\text { fiber : shell/ } \\
2.5: 0.5\end{array}$ & Successful & - & 4 & 38 & 35 \\
\hline 15 & 45 & $\begin{array}{l}\text { fire-wood : shell/ } \\
0.5: 2.5\end{array}$ & Successful & 13 & 23.5 & 80 & 59 \\
\hline 15 & 45 & $\begin{array}{l}\text { Fire-wood: fiber/ } \\
1: 1\end{array}$ & Successful & 5 & 48.9 & 85 & 60 \\
\hline 15 & 45 & $\begin{array}{l}\text { Fire-wood: } \\
\text { shell : fiber/ } \\
1: 2: 1\end{array}$ & Successful & 7.2 & 41 & 69 & 58 \\
\hline
\end{tabular}

Table 2. The results of combustion test (force convection air $18.7 \mathrm{~m}^{3} /$ minutes)

\begin{tabular}{|c|c|c|c|c|c|c|c|}
\hline \multirow[t]{2}{*}{$\begin{array}{l}\text { Damper } \\
\text { opened, cm }\end{array}$} & \multirow{2}{*}{$\begin{array}{l}\text { The height of } \\
\text { grate from the } \\
\text { floor, cm }\end{array}$} & \multirow[t]{2}{*}{$\begin{array}{l}\text { Biomass fuel/ } \\
\mathrm{kg}\end{array}$} & \multirow[t]{2}{*}{$\begin{array}{l}\text { Combustion } \\
\text { proceed }\end{array}$} & \multirow[t]{2}{*}{$\begin{array}{l}\text { Time to boil the } \\
\text { water, minute }\end{array}$} & \multirow[t]{2}{*}{$\begin{array}{l}\text { Average rate of water } \\
\text { vaporized, minute/ } \mathrm{ml}\end{array}$} & \multicolumn{2}{|c|}{$\begin{array}{l}\text { Maximum } \\
\text { temperature, }{ }^{0} \mathrm{C}\end{array}$} \\
\hline & & & & & & oven & Chimney \\
\hline \multirow{3}{*}{2.5} & \multirow{3}{*}{25} & fire-wood/ 2 & successful & 8 & 12.6 & 58 & 50 \\
\hline & & shell/ 2 & bad & - & - & 34 & 32 \\
\hline & & fiber/ 2 & bad & - & - & 35 & 32 \\
\hline \multirow{3}{*}{10} & \multirow{3}{*}{45} & fire-wood/ 2 & successful & 9 & 12 & 49 & 40 \\
\hline & & shell/ 2 & bad & - & - & 44 & 39 \\
\hline & & fiber/ 2 & bad & - & - & 42 & 38 \\
\hline \multirow{3}{*}{10} & \multirow{3}{*}{45} & shell/ 3 & Failed & - & - & - & - \\
\hline & & shell : fiber/ & & & & & \\
\hline & & $1: 1$ & successful & 6 & 26.4 & 48 & 43 \\
\hline \multirow{4}{*}{15} & \multirow{4}{*}{45} & shell : fiber & bad & - & - & 45 & 42 \\
\hline & & $1.5: 0.5$ & & & & & \\
\hline & & shell : fiber & bad & - & - & 47 & 42 \\
\hline & & $2: 1$ & & & & & \\
\hline
\end{tabular}



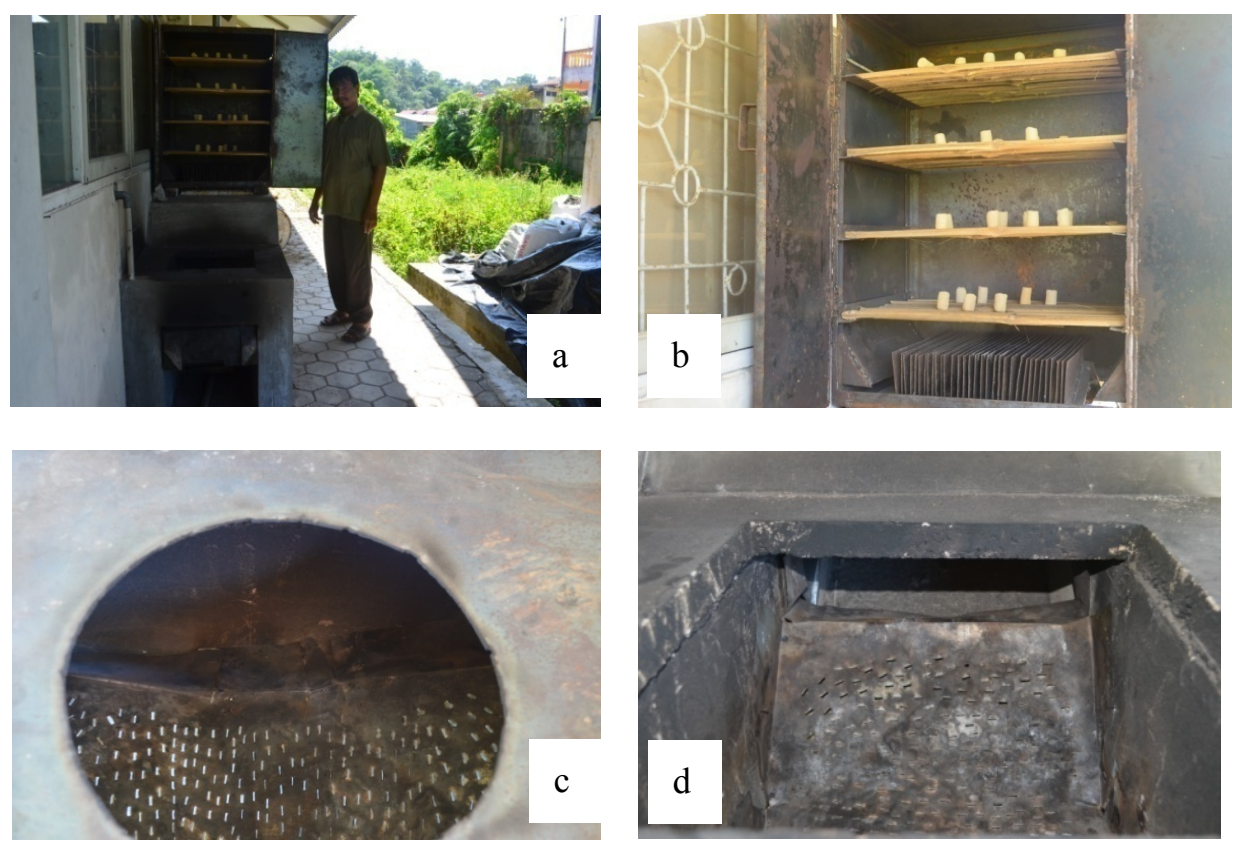

Figure 3. (a) Construction of neo-local WS Stove; (b) oven equipped with pin at the bottom; (c) grate for biomass bed and pot hole; (d) channel of flue gas from combustion chamber to chimney

Combustion test results with natural convection air presented in Table 1 showed that parameters under studied namely: the height of damper in the opening of flue gas channel, the height of grate for biomass bed from the floor, kinds of biomass fuel and their quantitative proportion influenced the responses variables as follow: combustion proceed, boiling time operation, average rate of water vaporized, and maximum temperature achieved in the oven and chimney. Variation of damper opening from 2.5 to $20 \mathrm{~cm}$ in the opening of flue gas channel to chimney influences oxygen gas present in combustion chamber and consequently determines combustion proceed. Too small opening damages combustion operation since backward flow of flue gas going on predominantly rather than goes forward to chimney and heat transfer to cooking pot reduced significantly while $\mathrm{CO}_{2}$ gas accumulates in the chamber to give poison effect on combustion. Conversely, too large opening increases heat loss in flue gas. The height of damper opened around 10 to $15 \mathrm{~cm}$ showed better performances in combustion in case of natural convection air to combustion chamber. Besides, it also showed better range of drying air temperature in the oven and lower flue gas temperature exit the chimney.

The height of grade from the floor of combustion chamber determines the distance between the flare and the bottom of pan. The height of grade $45 \mathrm{~cm}$ from the floor gives better contact between the flare and the bottom of pan to well utilized heat of combustion so that combustion proceeds successfully to boil the water. For the height of grade $25 \mathrm{~cm}$ from the floor and two kilograms of each kind of biomass fuel, there is no direct contact between the flare and the bottom of pan. The distance between the flare and the bottom of pan is still far enough, depend on the kind of fuel, namely around 15 to $25 \mathrm{~cm}$ for fire-wood, 5 to $15 \mathrm{~cm}$ for fiber, and 30 to $40 \mathrm{~cm}$ for shell. The large distance between the pot and fuel bed causes heat transfer to cooking pot to be considerably reduced.

Kinds of biomass fuel and their quantitative proportion used in the mixtures determine strongly combustion proceed behavior as shown in Table 1. In cases of combustion by natural convection air, fire-wood fuel still shows the best performance as it contains volatile matters around 76 to $86 \%$ while the shell fuel shows the worst perhaps it is more stiff, compact, and likely nonporous material. Meanwhile, the fiber fuel shows unique characteristic in combustion. Although easier to burnt, the fiber does not give stable flare. Combustion test result showed that the flare could only stand for less than 10 minutes so that it failed to boil the water. Fiber shows similar behavior to "katapang", the additional fuel traditionally used in LWS Stove for boiling gambir.

Kinds of biomass fuel and their quantitative proportion used in combustion influence the normal boiling time which is in the range of 5 to 13 minutes. Fire-wood plays an important role in the average rate of water vaporized (20 to $50 \mathrm{ml} /$ minutes) since it gives stable flare in combustion. In the absence of fire-wood, the average rate of water vaporized is relatively lower ( 4 to $10 \mathrm{ml} /$ minutes) caused by unstable and small flame from fiber and shell burnt. 
Any alternatives of biomass fuel used promises flue gas heat utilization for drying operation. The drying air in the oven is hot enough for drying operation. Its temperature in the oven from higher to lower is produced by fire-wood, fiber, and shell respectively, in the range of $40-95{ }^{\circ} \mathrm{C}$. Meanwhile, measurement of stack gas temperature and its fly ash content give interest results, especially in health and safety and heat efficiency of stove aspects.

Flue gas test result showed that stack gas temperature is less than $65{ }^{\circ} \mathrm{C}$ and no fly ash content detected in the stack gas. The lower stack gas temperature means lower heat loss in flue gas and indicates higher heat efficiency of the stove. Fly ash content in stack gas was detected by white filter placed in chimney. Test results showed that there had no change in color and in the weight of the white filter. In fact, the fly ash accumulated in as long as the flue gas channel and in the lower plates of pin. So, the pin beneath the oven is functioned to transfer effectively the heat from the flue gas to drying air as well as to trap the fly ash.

Combustion test results with force convection air $18.7 \mathrm{~m}^{3} /$ minutes showed in Table 2. Force convection air using fan did not give much influence on combustion of shell, except for mixture of 1:1 by weight of shell and fiber. It showed a good flare and boiled the water effectively. Nevertheless, only some of the shell fed is burnt-out. Small flame on combustion of shell presents on de-volatilization or pyrolysis step. Meanwhile, the combustion of its char presents ember only.

To operate the stove with force convection air shows at least two weaknesses, namely: first, it needs fan or blower and power source; second, dilution effect. The first one caused additional capital investment and operational cost. The second reduces stove and oven temperatures so as to reduce heat efficiency and performance of oven in drying operation.

Flue gas analysis showed that air emission load was $2,2 \mathrm{~m}^{3} /$ minutes and flue gas composition was shown in Table 3. Comparison of CO gas content in air emission test result (590 compare to $700 \mathrm{ppm}$ ) showed that combustion in NWS Stove proceeded more complately than in LWS Stove. Then, lower temperature stack $\left(50{ }^{\circ} \mathrm{C}\right.$ or less) showed higher accumulation and heat efficiency in NWS Stove compare to LWS Stove which was around $150-200{ }^{\circ} \mathrm{C}$.

Tabel 3. Air emission analysis of neolocal stove

\begin{tabular}{lll}
\hline Parameter & Units & Test Result \\
\hline Nitrogen Dioksida $\left(\mathrm{NO}_{2}\right)$ & Ppm & 157 \\
Carbon monoksida $(\mathrm{CO})$ & $\mathrm{Ppm}$ & 590 \\
Carbon Dioksida $\left(\mathrm{CO}_{2}\right)$ & $\%$ & 8,3 \\
Oksigen $\left(\mathrm{O}_{2}\right)$ & $\%$ & 11,8 \\
Temperatur stack & ${ }^{0} \mathrm{C}$ & 58 \\
\hline
\end{tabular}

\subsection{Temperature Profiles in Combustion Chamber}

Temperature profiles in combustion chamber with variation of kind and quantitative proportion of biomass fuel on three different height positions are shown in Figures 4 to 6 . The length of combustion times and temperature profile varied significantly which depend on kinds of biomass fuel or quantitative proportion of their mixtures. In the fuel bed, the fire moves downward while the combustion air moves from sides and beneath. Temperature profile can be used as guidance to plan the feeding of fuel to keep operation temperature in order the pan can keep absorb heat efficiently. Additionally, the measurement of temperature on kerosene and LPG stoves, for comparison, gives the value of $477{ }^{\circ} \mathrm{C}$ and $486{ }^{\circ} \mathrm{C}$ respectively. 


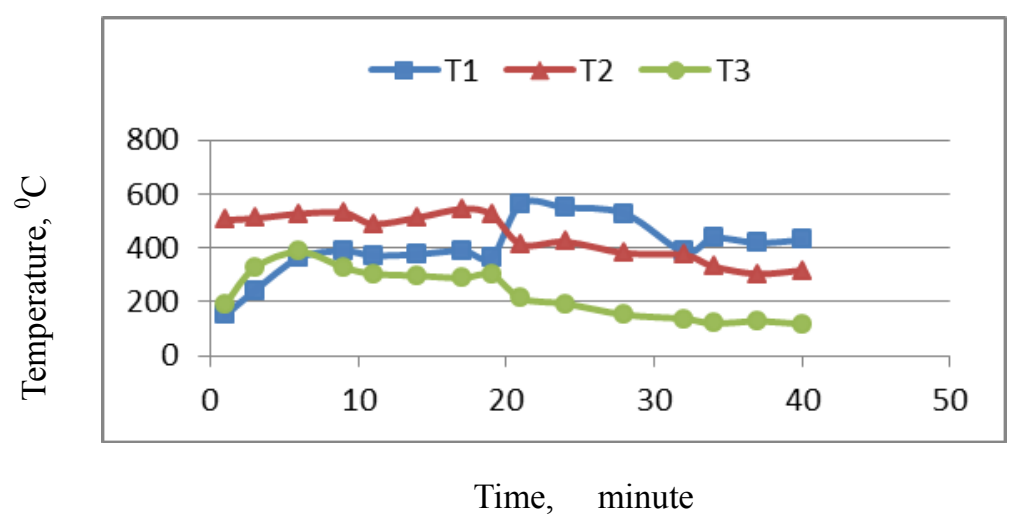

Figure 4. Temperature profile in combustion chamber for mixture of 3 kilograms of shell and 1 kilogram of fire-wood

For the mixtures of 3 kilograms of shell and 1 kilogram of fire-wood, the flame stands up until minute to 40 and temperature profile is shown at Figure 4. The flare is dictated by de-volatilization/pyrolysis of fire-wood signed with temperature $\mathrm{T}_{2}$ value which is around $500{ }^{\circ} \mathrm{C}$. It can be seen that until minute to 6 , though nearest to the bed fuel, the value of temperature $\mathrm{T}_{1}$ is the lowest and noted by sharp inclining, namely from 150 to $390{ }^{\circ} \mathrm{C}$. This phenomenon is probably caused by some absorption of heat of combustion in biomass drying step, especially by shell, while the source of fire is actually from combustion of some fire-wood. It is going on until minute to 18 and temperature $\mathrm{T}_{1}$ value is relatively stable at around $390{ }^{\circ} \mathrm{C}$. Starting at minute to 20 , de-volatilization/pyrolysis step of combustion of fire-wood comes to the end and the flare reduces significantly. Then the temperature in combustion chamber is dictated by de-volatilization/pyrolysis of the shell and combustion step of char. Combustion in this step is going on with small flame or indeed tends to ember. Consequently, the higher temperature is at the lower section of combustion chamber, namely temperature $\mathrm{T}_{1}$ which its value is at around 580 to $420{ }^{\circ} \mathrm{C}$.

Until minute to 17 the temperature $\mathrm{T}_{2}$ value is the highest, namely around and above $500{ }^{\circ} \mathrm{C}$. It is probably caused by the flare and temperature $\mathrm{T}_{2}$ position which is nearest to the flare at de-volatilization/pyrolysis step of combustion. Around minute to 20 , the flare declines relatively sharp and so temperature $\mathrm{T}_{2}$ value drop to $400{ }^{\circ} \mathrm{C}$. Its value is still at above $300{ }^{\circ} \mathrm{C}$ in the last minute probably because of heat of radiation from combustion of char at the lower section of chamber.

Meanwhile, temperature $T_{3}$ value, which is measure of heat nearest to pot, is always the lowest since the flame is medium to small, except at the beginning of combustion operation with the flare covers the bottom of pan. Until minute to 18 , temperature $\mathrm{T}_{3}$ value is still at around $300{ }^{\circ} \mathrm{C}$. Then, starting from de-volatilization/pyrolysis step of shell and char combustion which produce the small flame, the value of temperature $\mathrm{T}_{3}$ is the lowest and representation of heat of radiation, namely at around 200 to $120^{\circ} \mathrm{C}$.

For the mixtures of 2.5 kilograms of shell and 1.5 kilogram of fire-wood, the flame holds on until minute to 67 . The length of combustion time increases $60 \%$ by changing quantitative proportion of shell to fire-wood from 3:1 to $5: 3$. Additional portion of fire-wood in the mixture improved flame significantly because the flame actually comes from fire-wood combustion. Temperature profile is shown at Figure 5. It can be seen that until minute to 27 there is a fluctuation with tends to increase in the temperature $\mathrm{T}_{1}$ value, namely from 143 to $300{ }^{\circ} \mathrm{C}$. This phenomenon is probably caused by excessive updraft through fuel bed and absorption of some heat of combustion in the step of biomass drying. In the minute to 30 , temperature $T_{1}$ value is increase rapidly to above $500{ }^{0} \mathrm{C}$ which indicates de-volatilization/pyrolysis step of combustion of biomass fuel at the lower section of combustion chamber. It can be seen in the picture that until minute to 67 there is a fluctuation with temperature $\mathrm{T}_{1}$ value in the range of 420 to $520{ }^{\circ} \mathrm{C}$. It mainly caused by wind factor as well as random distribution of shell and fire-wood. 


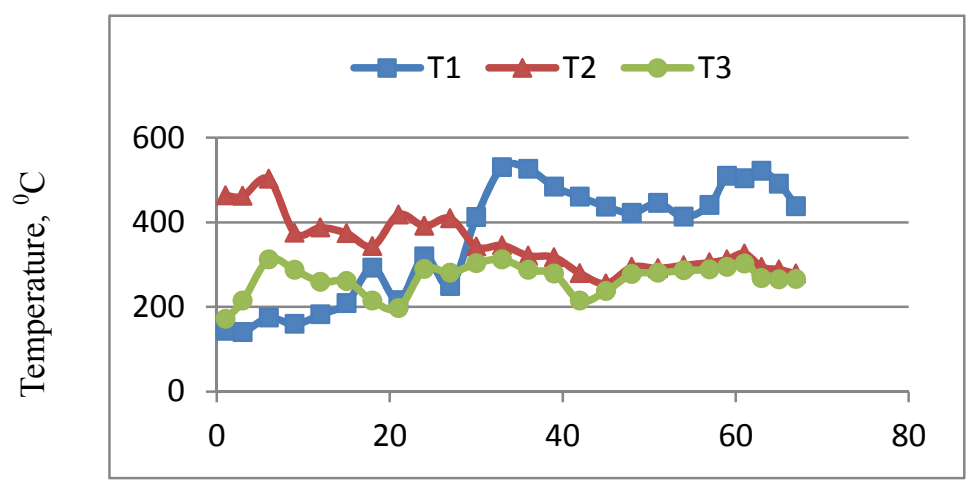

Time, minute

Figure 5. Temperature profile in combustion chamber for mixture of 2.5 kilograms of shell and 1.5 kilograms of fire-wood

Until minute to 27 the temperature $\mathrm{T}_{2}$ value is the highest, namely in range of 500 to $350{ }^{\circ} \mathrm{C}$. It is because of the flare and temperature $T_{2}$ position nearest to the flare at de-volatilization/pyrolysis step of combustion. Since minute to 30 till the end of combustion the temperature $\mathrm{T}_{2}$ value tends to held on about $300{ }^{\circ} \mathrm{C}$. It is because of heat of radiation from combustion of char at the lower section of chamber.

Meanwhile, until minute to 16 , where the flame is large to medium, the value of temperature $T_{3}$ is still higher than $T_{1}$. Temperature $T_{3}$ value which is the representation of heat of radiation is always the lowest as long as combustion proceed with the small to medium flame, namely it is around 200 to $300{ }^{0} \mathrm{C}$. In de-volatilization/pyrolysis step of combustion of shell and char, the temperature $\mathrm{T}_{3}$ value is the lowest. However, it is still in the range of 200 to $300{ }^{\circ} \mathrm{C}$.

For the mixtures of 2 kilograms of shell, 1 kilogram of fiber, and 1 kilogram of fire-wood, combustion proceed faster and the flame hold on until minute to 25 . Additional of $25 \%$ of fiber in the biomass fuel mixtures makes combustion proceeds more uniformly and faster. The flare at the beginning caused predominantly by the fiber and then followed by fire-wood. Temperature profile is shown at Figure 6. It can be seen that until minute to 15 temperatures $T_{1}$ and $T_{2}$ values are high and fluctuate around $500{ }^{\circ} \mathrm{C}$ or above. They are because of the flare and temperature $T_{1}$ and $T_{2}$ position nearest to the flare at de-volatilization/ pyrolysis step of combustion of fiber and fire-wood.

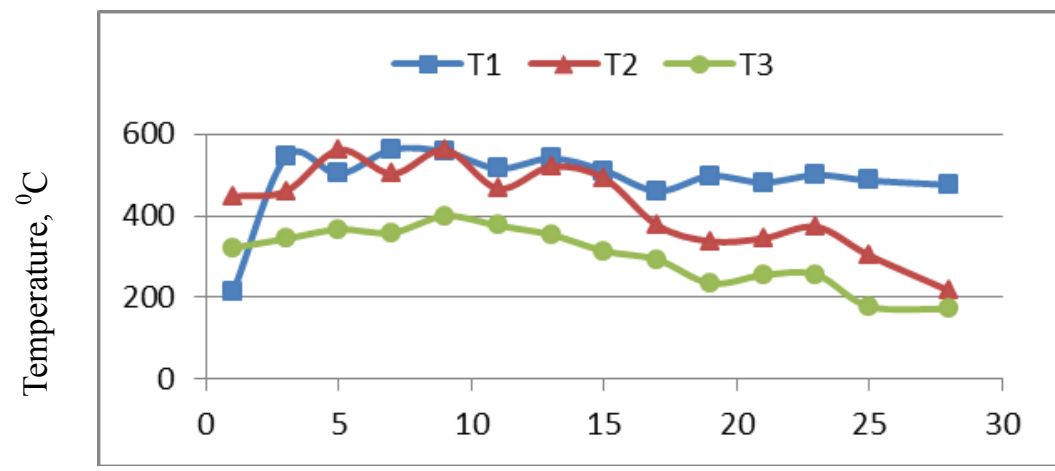

Time, minute

Figure 6. Temperature profile in combustion chamber for mixture of 2 kilograms of shell, 1 kilogram of fiber, and 1 kilogram of fire-wood

Though the flame has been dimmed since minute to 15 , temperature $T_{1}$ value is still high as long as combustion proceeds until minute to 25 , namely fluctuate around $490{ }^{\circ} \mathrm{C}$. It is caused by heat generated by ember from char combustion of shell, fiber, and fire-wood at the lower section of chamber. Meanwhile, temperature $\mathrm{T}_{2}$ decreases 
sharply from 500 to $217^{\circ} \mathrm{C}$.

For temperature $\mathrm{T}_{3}$, until minute to 15 its value is in the range of 300 to $400{ }^{\circ} \mathrm{C}$. However, it is then decrease to reach $170{ }^{\circ} \mathrm{C}$ at minute to 25 . Clearly, supported by its physical characteristics, fiber plays a role to keep the flare in chamber. In addition, temperature in combustion chamber is really different from bottom to top so that adjustable grate for fuel bed is very important to set the distance between fuel and pot in order to optimize heat transfer to cooking pot.

\subsection{Heat Efficiency in NWS Stove and Oven}

Heat efficiency calculation in NWS Stove and oven based on experiment data using mixture of biomass fuel of each $1 \mathrm{~kg}$ fiber, shell, and fire-wood respectively. The mixture completely burnt out with heating value of $19.1+$ $20.9+19.0=59.0$ MJ. Water boiled in pan is 5 kilograms. Boiled water rest in pan at the end of boiling is 1.55 kilograms. Moisture in samples before and after drying is $20 \%$ and $5 \%$ respectively. Drying air entering and exit from the oven is 68 and $65{ }^{\circ} \mathrm{C}$. Heat balances calculation in the stove as boiling unit gives heat efficiency $15.8 \%$ while total heat efficiency in the stove and oven is $18.78 \%$.

Heat efficiency calculation showed that prototype NWS Stove improve efficiency of local stove significantly, namely $18.78 \%$ compare to $11.6 \%$ for local stove efficiency. For boiling unit, comparison of efficiency is $15.8 \%$ compare to $11.6 \%$. It means that NWS Stove can save $36.2 \%$ fuel. This efficiency is consistent with Improved Plancha stove [4] and it is a little higher then cottage basin stove one as showed by Sankey diagram at Figure 7. Heat efficiency of cottage basin stove is $11.7-15.3 \%$.

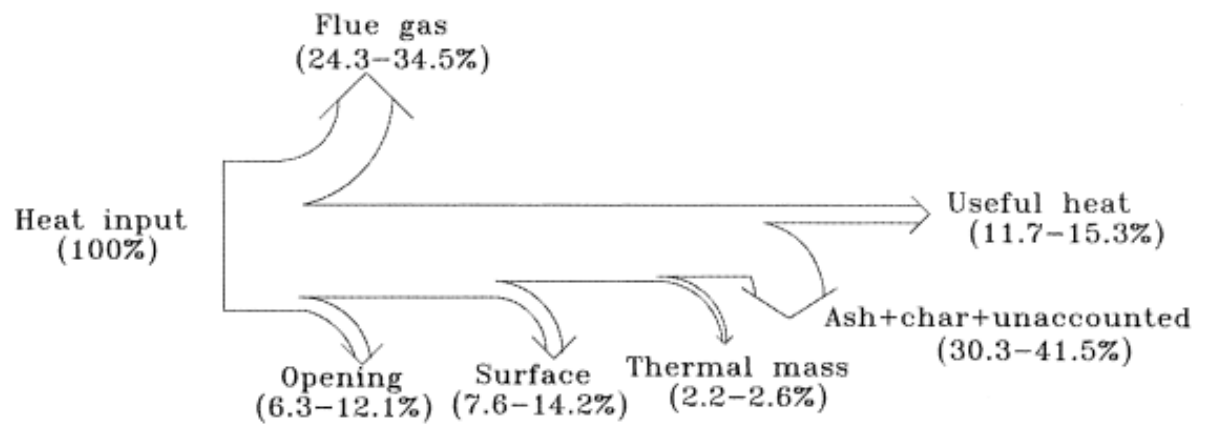

Figure 7. Sankey diagram showed heat flows in cottage basin stove

If $70 \%$ of fire-wood fuel is then substituted by the mixtures of shell and fiber, NWS Stove will consume fire-wood only less than $20 \%$ of local stove needs. For boiling gambir in Pesisir Selatan Province for example, it needs only 400 kilograms of fire-wood per day compare to 20 tons consumed by local stove. Since the dimension of fire-wood used in NWS Stove is small, namely 15 to $20 \mathrm{~cm}$ length and effective diameter of $2 \mathrm{~cm}$, then it can get from small branches. So NWS Stove is green that it possibly does not need to cut trees anymore for fire-wood. It is also as simple as local stove to operate NWS Stove since addition of biomass fuel can be done through the opening while ash is accumulated in the floor under combustion chamber.

\section{Conclusion}

The NWS Stove designed for integrated boiling gambir and heat utilization in oven dryer is improved stove promises better performances. It can be operated as simply as LWS Stove. The height of damper opened around 10 to $15 \mathrm{~cm}$ showed better performances in combustion in case of natural convection air to combustion chamber. The distance between the grade and pot around $25 \mathrm{~cm}$ gives better contact between the flare and the bottom of pan to utilize the heat of combustion effectively so that combustion proceeds successfully to boil the water. Furthermore, temperature profiles in combustion chamber show that the best distance between fuel bed and pot is around 10 to $15 \mathrm{~cm}$ for the reason of heat transfer efficiency. Kinds of biomass fuel and their quantitative proportion used in the mixture influence strongly the combustion proceed and certainly temperature profile in combustion chamber. In cases of combustion by natural convection air, fire-wood fuel still shows the best performance while the shell fuel shows the worst. Meanwhile, the fiber fuel shows unique characteristic in combustion, namely easier to burn but does not give stable flare. Total heat efficiency in the stove and oven is $18.78 \%$ while LWS Stove efficiency is only $11.6 \%$. Any alternatives of biomass fuel used promises flue gas heat utilization for drying operation with the range of drying air temperature in oven from 40 to $95{ }^{\circ} \mathrm{C}$. Stack gas 
temperature less than $65{ }^{\circ} \mathrm{C}$ and no fly ash content detected in the stack gas indicate that the stove promises health and safety aspect.

Economically, the NWS Stove needs capital investment minimal 50 USD, two and half times higher than capital investment of LWS Stove, but it might stand for many years. The NWS Stove, with any quantitative proportion of mixture of fire-wood, fiber, and shell, promises new alternative to overcome local deforestation impact due to LWS Stove activities. It saves the fuel and green and possibly to reduce fire-wood need more than $70 \%$.

Based on this study, it is recommended to explore others potential local biomass fuels such as corncob, cocoa and durian shell, and to apply biomass pellet and briquette technology.

\section{Acknowledgements}

The authors are grateful to Bung Hatta University Rector and vices-rector for the sustained encouragement by them throughout the course of this study. Special thanks are due to Prof. DR. Ir. Eddy Ibrahim, M.Sc, Chairman of Doctoral Program of Environmental Science of Sriwijaya University, for his guidance throughout the course of this study. Thanks are due to Mr. Masrizal et al. for their help in combustion test of NWS Stove.

\section{References}

Baldwin, S. F. (2006). Biomass Stove: Engineering Design, Development, and Dissemination.

Borman, G. L. and Ragland, K. W. (1998). Combustion Engineering.

Boy, E. et al. (2000). Fuel Efficiency of an Improved Wood-burning Stove in Rural Guatemala: Implications for Health, Environment and Development. Energy for Sustainable Development. http://dx.doi.org/10.1016/S0973-0826(08)60239-2

Firdaus et al. (2013). Design of Neo-local West Sumatera Stove for Boiling Gambir (Uncaria Gambir Roxb.), The $4^{\text {th }}$ International Seminar on Environmental Engineering, Bali, Indonesia.

Hasbullah. (2001). Teknologi Tepat Guna Agroindustri Kecil Sumatera Barat, Dewan Ilmu Pengetahuan, Teknologi dan Industri Sumatera Barat.

Hossain, M. M. G. (2003). Improved Cookstove and Biogas Programmes in Bangladesh. Energy for Sustainable Development, 7(2), 97-100. http://dx.doi.org/10.1016/S0973-0826(08)60359-2

Improved Cook Stoves, http://www.appropedia.org/Improved_stoves

Justa Stoves. (n.d.). Saving Carbon and Improving Lives in Guatemala and El Salvador. Retrieved from http://www.stovesonline.co.uk/justa-stove.html

Karen, W. (n.d.). Standard Stoves Performance Testing. Retrieved from http://darfurstoves.org/downloads/Cookstove_Testing_Brief.pdf

Lokras, S. S. (2012). Development and Dissemination of Fuel-efficient Biomass Burning Devices, India: Indian Institute of Science.

Lundgren, J. (2004). Basic Principles of Biomass Combustion.

Mande, S. et al. (2000). Study of Stoves Used in the Silk-reeling Industry, Biomass \& Bioenergy. http://dx.doi.org/10.1016/S0961-9534(00)00021-0

Mark, B. et al. (n.d.). Design Principles for Wood Burning Cook-stoves, pp 12-16. Retrieved from $\mathrm{http} / / /$ bioenergylists.org/stovesdoc/Pcia/DesignPrinciplesforWoodBurningCookstoves.pdf

Plancha Stove, http://www.google.co.id/plancha+stove

Pusat Studi Lingkungan Hidup Daerah (PSLHD) Sumatera Barat, (2012).

Rosie, C. C. et al. (2008). Biomass - An Important Renewable Source of Energy in Romania, Environmental Engineering and Management Journal.

\section{Copyrights}

Copyright for this article is retained by the author(s), with first publication rights granted to the journal.

This is an open-access article distributed under the terms and conditions of the Creative Commons Attribution license (http://creativecommons.org/licenses/by/3.0/). 